\title{
KINERJA PERAWAT DI RUANG RAWAT INAP RSU SARAH KOTA MEDAN DITINJAU DARI GAYA KEPEMIMPINAN DAN KOMUNIKASI KEPALA RUANGAN
}

\section{PAHALA M J SIMANGUNSONG ${ }^{1}$, NURUL WAHYUNI ${ }^{2}$, DIAH AYU SOUCHI ${ }^{3}$, RIHAN WIRDA ASDANI ${ }^{4}$, MAFE ROBBI SIMANJUNTAK ${ }^{5}$, PERRY BOY CHANDRA SIAHAAN ${ }^{6}$, MASRYNA SIAGIAN ${ }^{7}$}

$1,2,3,4,5,6,7$ Universitas Prima Indonesia Jalan Sekip Simp. Sikambing, Sei Putih Timur I, Kec. Medan Petisah, Kota Medan, Sumatera Utara 20111 Email: nurul.wahyuni1998@gmail.com

$$
\text { DOI : } 10.35451 / j k f . v 3 i 1.536
$$

\begin{abstract}
Nursing performance is a work achievement shown by nurses in order to produce good output for patients and the nurses themselves, in this case the head of the room is a component that plays an important role in producing good performance. This research was conducted by researchers by distributing questionnaires, it was found that many nurses said that the head of the room did not acknowledge the work progress achieved by nurses, there was no warning made to nurses who made mistakes, never gave rewards as recognition of nurse performance, did not show this things that can attract nurses' work interest, do not carry out routine supervision of nursing tasks. This research was conducted at the Medan City Sarah General Hospital in 2020 with the aim of knowing the relationship between leadership style and communication of the head of the room with the performance of inpatient nurses. The design of this study was an analytic survey using a cross sectional design with 25 respondents. Based on the results of the chi-square test, it was found that there was no relationship between leadership style and performance of inpatients with results of $\rho$-value $(1,000)>0.05$ and there was a relationship between communication and performance of inpatients with results of $\rho$-value $(0.002)<0,05$. The conclusion was that there was no relationship between leadership style and performance, but there was a relationship between communication and inpatient performance at Sarah General Hospital in 2020. It was hoped that each head of the room could apply a leadership style that was appropriate to the situation and conditions and can communicate well so that it can produce good performance.
\end{abstract}

Keywords: Leadership Style, Communication, Nurse Performance

\section{PENDAhUluan}

Ada tiga hal yang mempengaruhi kinerja yaitu diantaranya faktor individu, organisasi, dan psikologis. Faktor individu meliputi kemampuan dan keterampilan. Psikologis meliputi persepsi, sikap, kepribadian, belajar, dan motvasi. Organisasi meliputi perilaku dan kinerja individu, kepemimpinan, intensif, supervisi, struktur, dan desain pekerjaan (Triwibowo, 2013). Kinerja yang diberikan merupakan hasil capaian yang akan dicapai oleh perawat (Prima dkk, 2019). 
Penelitian Handayani dkk (2018), menunjukkan adanya hubungan yang signifikan antara kepemimpinan dengan kinerja. Peneliti menemukan bahwa dari 45 responden sebanyak $64,3 \%$ responden memiliki kinerja dan kepemimpinan kurang baik, berdasarkan asumsi peneliti kepemimpinan dikatakan kurang baik dikarenakan pemimpinan tidak mendorong giat kepada karyawannya dan tidak dapat menyelesaikan masalah yang merupakan prioritas.

Seorang pemimpinan yang mendukung dan dapat membangun hubungan baik dengan karyawan akan meningkatkan motivasi secara positif bagi karyawan dalam bekerja untuk mencapai tujuan organisasi. Teori ini didasarkan pada studi perilaku organisasi yang menunjukkan bahwa orang lebih bahagia dan lebih puas dalam pekerjaan ketika mereka memiliki pemimpin yang mendukung yang berempati (Al-Sawai, 2013).

Dalam menerapkan komunikasi dalam organisasi terdapat banyak gaya kepemimpinan yang bisa digunakan atau diterapkan. Tidak ada penerapan gaya kepemimpinan paling tepat karna pemimpin berkomunikasi dengan bawahannya dapat menerapkan banyak gaya kepemimpinan sesuai dengan situasi dan kondisi. Gaya kepemimpina juga dapat dipersentasikan sebagai sebuah kekuasaan antara atasan dengan bawahan (Mahmudah, 2015).

Dalam penelitian Idris dan Haskas (2017), menyimpulkan bahwa adanya hubungan yang bermakna antara gaya kepemimpinan demokratis $(\rho=0,015)$ otoriter $(\rho=0,011)$ dan liberal $(\rho=0,002)$ dengan kinerja perawat di ruang inap RSUD Labuang Baji Makassar.

Menurut

menemukan adanya hubungan komunikasi (keterbukaan, empati, sikap mendukung) dengan kinerja perawat pelaksana ruang rawat inap. Dengan hasil bivariat keterbukaan dengan kinerja diperoleh $(\rho=0.006)$ ada korelasi yang signifikan, empati dengan kinerja nilai $(\rho=0,001)$ ada korelasi yang signifikan, sikap mendukung dengan kinerja nilai $(\rho=0,016)$ ada korelasi yang signifikan. Seorang perawat yang baik yaitu yang mampu berkomunikasi dengan ramah dan berempaty untuk emningkatkan pelayanan yangbaik ke pasien (Sembiring dan Munthe, 2019).

Rumah Sakit Umum Sarah adalah rumah sakit yang berada di Kota Medan dan ditetapkan sebagai rumah sakit dengan klasifikasi D. Berdasarkan hasil survei awal yang kami dapat, setelah membagikan kusioner kepada 10 perawat ditemukan 7 perawat yang mengatakan bahwa kepala ruangan tidak mengakui kemajuan kerja yang dicapai oleh perawat dan 9 perawat yang mengatakan bahwa tidak adanya teguran kepada perawat yang melakukan kesalahan. Sehingga mempengaruhi kinerja perawat dan akan mempengaruhi mutu kualitas pelayanan yang diberikan kepada pasien. Penelitian ini bertujuan untuk mengetahui hubungan gaya kepemimpinan dan komunikasi kepala ruangan dengan kinerja perawat rawat inap.

\section{METODE PENELITIAN}

Penelitian ini merupakan survei analitik dengan desain cross sectional yang bertujuan untuk mengetahui hubungan gaya kepemimpinan dan komunikasi kepala ruangan dengan kinerja perawat rawat inap.

Populasi penelitian sebanyak 25 orang dan sekaligus menjadi sampel penelitian (total sampling). Pengumpulan data dilakukan dengan cara membagikan kuesioner dengan alternatif jawaban ya dan tidak pada variabel gaya kepemimpinan dan 
komunikasi, menggunakan pertanyaan dengan skala likert pada variabel kinerja perawat. Penelitian ini menggunakan uji chi-square $\mathrm{X}^{2}$ pada tingkat kepercayaan 95\% ( $a=0,5)$ hubungan antara variabel bebas dan variabel terikat dapat di lihat apabila nilai $\rho$ value $<0,05$ maka $\mathrm{H}_{0}$ ditolak dan $\mathrm{H}_{a}$ diterima.

\section{HASIL}

Tabel 1. Distribusi Karakteristik Responden

\begin{tabular}{lcc}
\hline Karakteristik & $(\mathbf{f})$ & $\mathbf{( \% )}$ \\
\hline Jenis Kelamin & & \\
\hline Laki - Laki & 0 & 0 \\
Perempuan & 25 & 100 \\
\hline Total & 25 & 100 \\
\hline Umur & & \\
\hline$\leq 30$ Tahun & 19 & 76,0 \\
$\geq 30$ Tahun & 6 & 24,0 \\
\hline Total & 25 & 100 \\
\hline Pendidikan & & \\
\hline SPK & 0 & 0 \\
D-III & 19 & 76,0 \\
Sarjana / Profesi & 6 & 24,0 \\
\hline Total & 25 & 100 \\
\hline Lama Kerja & & \\
\hline$\leq 5$ Tahun & 20 & 80,0 \\
$\geq 5$ Tahun & 5 & 20,0 \\
\hline Total & 25 & 100 \\
\hline
\end{tabular}

Dari tabel 1 diketahui karakteristik responden berdasarkan jenis kelamin didominasi oleh perempuan dengan jumlah responden sebanyak 25 orang $(100 \%)$. Sedangkan pada kelompok umur responden sebagaian besar berumur < 30 tahun sebanyak 19 orang $(76,0 \%)$. Responden dengan tingkat pendidikan D-III merupakan jumlah terbanyak yang menjadi sampel penelitian (19 orang). Selanjutnya kebanyakan responden bekerja selama $\leq 5$ tahun sebanyak 20 orang $(80,0 \%)$.
Tabel 2. Distribusi Frekuensi Gaya Kepemimpinan, Komunukasi, dan Kinerja Perawat

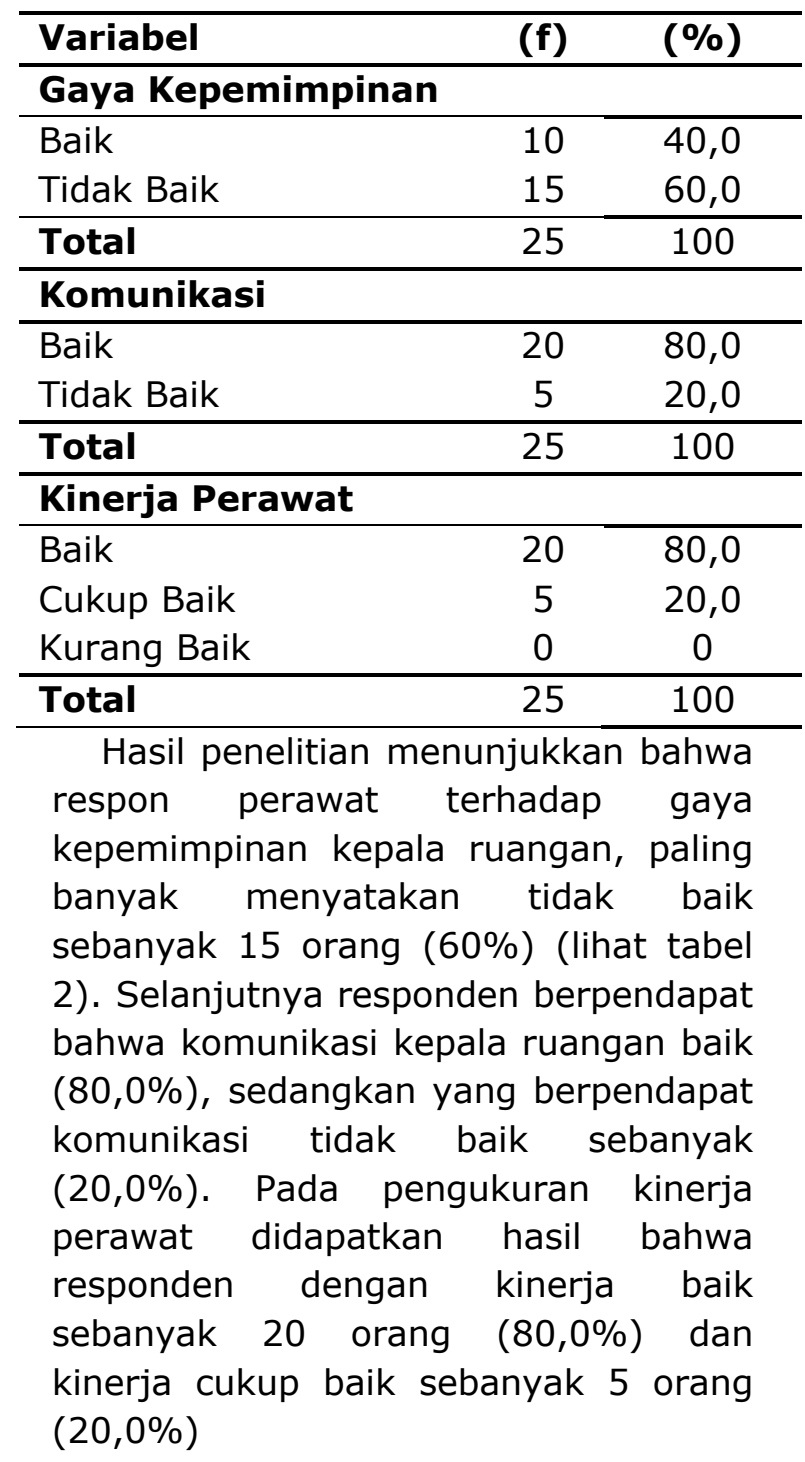

Tabel 3. Hubungan Gaya

Kepemimpinan Kepala Ruangan

Dengan Kinerja Perawat Rawat Inap

\begin{tabular}{|c|c|c|c|c|c|c|c|c|}
\hline \multirow{3}{*}{$\begin{array}{l}\text { Varia } \\
\text { bel } \\
\end{array}$} & \multicolumn{8}{|c|}{ Kinerja Perawat } \\
\hline & \multicolumn{2}{|c|}{ Baik } & \multicolumn{2}{|c|}{$\begin{array}{c}\text { Cuku } \\
\text { p }\end{array}$} & \multicolumn{2}{|c|}{$\begin{array}{l}\text { Kur } \\
\text { ang }\end{array}$} & \multicolumn{2}{|c|}{ Total } \\
\hline & $\mathbf{n}$ & $\%$ & $\mathbf{n}$ & $\%$ & $\mathbf{n}$ & $\%$ & $\mathrm{n}$ & $\%$ \\
\hline \multicolumn{9}{|c|}{ Gaya Kepemimpinan } \\
\hline Baik & 8 & 80 & 2 & 20 & 0 & 0 & 10 & 100 \\
\hline $\begin{array}{l}\text { Tidak } \\
\text { Baik }\end{array}$ & 12 & 80 & 3 & 20 & 0 & 0 & 15 & 100 \\
\hline
\end{tabular}


Diketahui dari 10 responden yang menyatakan gaya kepemimpinan baik, mayoritas reponden yang memiliki kinerja baik sebanyak 8 orang $(80,0 \%)$ dan minoritas responden yang memiliki kinerja cukup baik sebanyak 2 orang $(20,0 \%)$. Dari 15 reponden yang menyatakan gaya kepemimpinan tidak baik, mayoritas responden memiliki kinerja baik sebanyak 12 orang (80\%) dan minoritas responden memiliki kinerja cukup baik sebanyak 3 orang $(20,0 \%)$.

Hasil analisis bivariat dengan menggunakan uji chi-square diperoleh nilai $\rho$-value $=1,000(\rho$ value $>0,05)$, artinya Ho diterima, ini merupakan bahwa tidak ada hubungan yang signifikan antara gaya kepemimpinan dengan kinerja perawat rawat inap.

Tabel 4. Hubungan Komunikasi Kepala Ruangan Dengan Kinerja Perawat rawat Inap

\begin{tabular}{|c|c|c|c|c|c|c|c|c|}
\hline \multirow{3}{*}{$\begin{array}{l}\text { Varia } \\
\text { bel }\end{array}$} & \multicolumn{8}{|c|}{ Kinerja Perawat } \\
\hline & \multicolumn{2}{|c|}{ Baik } & \multicolumn{2}{|c|}{$\begin{array}{c}\text { Cuku } \\
\text { p }\end{array}$} & \multicolumn{2}{|c|}{$\begin{array}{l}\text { Kur } \\
\text { ang }\end{array}$} & \multicolumn{2}{|c|}{ Total } \\
\hline & $\mathbf{n}$ & $\%$ & $\mathbf{n}$ & $\%$ & $\mathbf{n}$ & $\%$ & $\bar{n}$ & $\%$ \\
\hline \multicolumn{9}{|c|}{ Komunikasi } \\
\hline Baik & 19 & 95 & 1 & 5 & 0 & 0 & 20 & 100 \\
\hline $\begin{array}{l}\text { Tidak } \\
\text { Baik }\end{array}$ & 1 & 20 & 4 & 80 & 0 & 0 & 5 & 100 \\
\hline p Valc & & 0,00 & & & & & & \\
\hline
\end{tabular}

Diketahui dari 20 responden yang menyatakan komunikasi baik, mayoritas reponden yang memiliki kinerja baik sebanyak 19 orang $(95,0 \%)$ dan minoritas responden yang memiliki kinerja cukup baik sebanyak 1 $(5,0 \%)$. Dari 5 reponden yang mengatakan komunikasi tidak baik, mayoritas responden memiliki kinerja cukup baik sebanyak 4 orang $(80,5 \%)$ dan minoritas responden memiliki kinerja baik sebanyak 1 orang $(20,0 \%)$..
Hasil analisis bivariat dengan menggunakan uji chi-square diperoleh nilai $\rho$-value $=0,002(\rho$ value $<0,05)$,

artinya Ho ditolak, ini merupakan bahwa ada hubungan yang signifikan antara komunikasi dengan kinerja perawat rawat inap.

\section{PEMBAHASAN}

\section{Hubungan Gaya Kepemimpinan Kepala Ruangan Dengan Kinerja Perawat Rawat Inap}

Berdasarkan hasil uji statistik menggunakan uji chi-square diperoleh $\rho$-value $=1,000(\rho$-value $<a)$ maka Ho diterima $\mathrm{Ha}$ ditolak sehingga dapat disimpulkan bahwa tidak ada hubungan gaya kepemimpinan kepala ruangan dengan kinerja perawat rawat inap.

Penelitian ini sejalan dengan penelitian Gannika dan Buanasari (2019), menyatakan bahwa tidak ada hubungan yang signifikan antara gaya kepemimpinan dengan kinerja perawat rawat inap dengan hasil penelitian sebesar $\rho$-value $=1,000(\rho$-value $>$ $0,05)$. Hasil penelitian dapat dikatakan bahwa gaya kepemimpinan kepala ruangan tidak bisa dipastikan, karena setiap kepala ruangan memiliki cara berbeda dalam mengatur atau memimpin bawahannya, hal tersebut juga dapat dilihat lagi berdasarakan situasi dan kondisi kepala ruangan menggunakan gaya kepemimpinan yang sesuai.

Penelitian ini juga sejalan dengan penelitian Perceka (2018), di RSUD DR. Slamet Garut menyatakan bahwa tidak ada pengaruh antara gaya kepemimpinan kepala ruanagan terhadap kinerja perawat pelaksana di Rumah Sakit Umum DR.Slamet Garut dengan hasil $(\rho$-value $=0,731) \rho$-value $0,731>0,05$ artinya $\mathrm{Ha}$ ditolak $\mathrm{Ho}$ diterima. Penelitian ini mengatakan bahwa dalam menjalankan tugasnya kepala ruangan memiliki gaya kepemimpinan tersendiri dalam 
memimpin. Dalam mencapai tujuan organisasi seorang pemimpin mampu menentukan gaya kepemimpinan sesuai dengan situasi dan kondisi dalam organisasi.

Penelitian dari Purba (2018), menyatakan bahwa pemilihan pemakaian gaya kepemimpinan yang efektif masih kurang dalam upaya meningkatkan kinerja perawat maka diperoleh $\rho$-value $=0,680(\rho$-value $>$ $0,05)$, Ho diterima Ha ditolak artinya bahwa tidak ada hubungan yang signifikan antara gaya kepemimpinan dengan kinerja perawat pelaksanaan. Kepemimpinan yang efektif merupakan seorang pemimpin yang dapat menerapkan gaya kepemimpinan yang tertentu dan disesuaikan dengan kelebihan dan kelemahan bawahan (Triyono, 2016). Kemungkinan seorang pemimpin boleh menggunakan gaya kepemimpinan yang berbeda (Ambarwati, 2014).

Hasil penelitian ini mengatakan bahwa kepala ruangan lebih dominan menggunakan gaya kepemimpinan demokratis sebanyak $(84,0 \%)$ ditinjau dari mayoritas perawat yaitu berjenis kelamin perempuan. Dalam penelitian Herachwati dan Basuki (2012), mengatakan bahwa ada perbedaan penggunaan gaya kepemimpinan yang dominan antara laki-laki dan perempuan, laki-laki lebih dominan menggunakan gaya kepemimpinan otoriter sedangkan perempuan lebih dominan menggunakan gaya kepemimpinan demokratis. Penggunaan gaya kepemimpinan demokratis kurang tepat diterapkan di rumah sakit yaitu dimana tindakan pemimpin (kepala ruangan) selalu melibatkan bawahan dan tergantung pada bawahan sehingga menyebabkan proses pengambilan keputusan yang menjadi lambat karena dalam situasi menangani pasien kritis memerlukan tindakan yang cepat (Putra dkk, 2014).

\section{Menurut Kurniadi (2013), mengatakan bahwa gaya} kepemimpinan dapat dikatakan baik apabila seorang pemimpin dapat menerapkan gaya kepemimpinan sesuai dengan kemampuan pemimpin pada situasi dan juga kondisi yang sedang berjalan atau dialami tidak hanya dominan pada penggunaan satu gaya kepemimpinan saja, jadi dapat dikatakan bahwa seorang pemimpin bisa menggunakan banyak jenis gaya kepemimpinan yang sesuai dengan masalah yang dihadapi dalam organisasi.

Penggunaan gaya kepemimpinan yang bermacam - macam dalam suatu organisasi dapat membantu menciptakan evektifitas kerja yang positif bagi anggota (perawat) sehingga apabila pemimpin dapat menerapkan gaya kepemimpinan yang sesuai dengan situasi dan kondisi organisasi maka anggota akan lebih bersemangat lagi dalam bekerja dan menjalankan kewajibannya (Putra dkk, 2014).

\section{Hubungan Komunikasi Kepala Ruangan Dengan Kinerja Perawat Rawat Inap}

Berdasarkan hasil uji statistika menggunakan uji chi-square diperoleh $\rho$-value $=0,002(\rho$-value $<0,05)$ maka Ho ditolak Ha diterima sehingga adanya hubungan komunikasi kepala ruangan dengan kinerja perawat rawat inap di Rumah Sakit Umum Sarah Tahun 2020.

Penelitian ini juga sejalan dengan penelitian Manalu (2014), di RSUD DR. Djasamen Saragih Pematang Siantar dengan jumlah sampel 54 orang dengan pengambilan sampel random sampling. Hasil penelitian menemukan adanya hubungan komunikasi (keterbukaan, empati, sikap mendukung) dengan kinerja perawat pelaksana ruang rawat inap. Kepala ruangan mengevaluasi asuhan keperawatan, hasil bivariat keterbukaan dengan kinerja diperoleh $\rho$ 
$=0.006$ ada korelasi yang signifikan, empati dengan kinerja nilai $\rho=0,001$ ada korelasi yang signifikan, sikap mendukung dengan kinerja nilai $\rho=$ 0,016 ada korelasi yang signifikan.

Peneliti menyatakan bahwa dari 25 responden, mayoritas yang menyatakan komunikasi baik pada kategori empati dan sikap mendukung sebanyak 20 orang $(80,0 \%)$ dan minoritas responden sebanyak 5 orang $(20,0 \%)$ mengatakan komunikasi dengan kategori keterbukaan.

Menurut Kurniadi

(2013), mengatakan bahwa Penerapan komunikasi dari atasan ke bawahan dan juga sebaliknya harus dipertahankan agar terhindar dari misscomunication (salah persepsi). Dalam penelitian Samodro dan Lestari (2018), mengatakan bahwa dari hasil penelitian yang dianalisis dengan menggunakan analisis regresi menunjukkan ada pengaruh komunikasi terhadap kinerja karyawan terkait alur komunikasi atasan dan bawahan secara signifikan dengan nilai $\rho$-value $=0,007<0,05$ maka dapat disimpulkan $\mathrm{Ho}$ ditolak dan $\mathrm{Ha}$ diterima. Komunikasi yang baik adalah komunikasi secara terbuka, dimana hubungan antar dua orang atau lebih untuk menyampaikan pesan yang berharga dalam organisasi (Kurniadi, 2013).

Komunikasi dapat dikatakan berhasil tidak hanya sebatas dalam penyampaian pesan tetapi harus juga bersifat terbuka karena dapat menghapus prasangka buruk ataupun kecurigaan yang mungkin terjadi dan dapat membangun rasa saling pengertian antara satu sama lain, melalui komunikasi terbuka memungkinkan para bawahan lebih leluasa dalam menyampaikan permasalahan yang dihadapi berkaitan dengan tugas - tugas yang diberikan oleh pemimpin (Dede, 2015).

\section{KESIMPULAN}

Ada hubungan komunikasi kepala ruangan dengan kinerja perawat rawat inap di Rumah Sakit Umum Sarah Kota Medan Tahun 2020 dengan $\rho$-value $(0,002)$.

Tidak ada hubungan gaya kepemimpinan kepala ruangan dengan kinerja perawat rawat inap di Rumah Sakit Umum Sarah Kota Medan Tahun 2020 dengan $\rho$-value $(1,000)$.

\section{DAFTAR PUSTAKA}

Ambarwati, Nia. 2014. "Gaya Kepemimpinan Yang Efektif Dalam Upaya Meningkatkan Kinerja Karyawan Pada PT. Sumber Mas Indah Plywood."

Al-Sawai, Abdulaziz. 2013. "Leadership of Healthcare Professionals: Where Do We Stand?"

Dede, Aisyah. 2015. "Keterkaitan Keterbukaan Komunikasi, Penghargaan Dari Pimpinan, Dan Partisipasi Pegawai Terhadap Kinerja Pegawai."

Gannika, Lenny, and Andi Buanasari. 2019. "Hubungan Gaya Kepemimpinan Kepala Ruangan Dengan Kinerja Perawat Di Ruang Rawat Inap Rumah Sakit GMIM Pancaran Kasih Manado."

Handayani, Sri, Puteri Fannya, and Putri Nazofah. 2018. "Faktor Yang Berhubungan Dengan Kinerja Tenaga Kesehatan Di Rawat Inap RSUD Batusangkar."

Herachwati, Nuri, and Bhaskaroga Dwiatmaja Basuki. 2012. "Gaya Kepemimpinan Laki - Laki Dan Perempuan."

Idris, Aldama, Alfiah A, and Yasir Haskas. 2017. "Hubungan Gaya Kepemimpinan Kepala Ruangan Terhadap Kinerja Perawat Dalam Melaksanakan

Asuhan Keperawatan Di Ruang Rawat Inap RSUD Labuang Baji Makassar."

Kurniadi, Anwar. 2013. Manajemen Keperawatan Dan Prospektifnya. Jakarta: Fakultas Kedokteran Universitas Indonesia. 
Mahmudah, Dede. 2015. "Komunikasi, Gaya Kepemimpinan, Dan Motivasi Dalam Organisasi."

Manalu, Jespin Saurlina. 2014. "Pengaruh Komunikasi Interpersonal Terhadap Kinerja Perawat Pelaksana Ruang Rawat Inap Di Rumah Sakit Umum Daerah DR. Djasamen Saragih Pematang Siantar." Sumatera utara.

Prima, Brema, Herbet Wau, and Marlinang Siagian. 2019. "Hubungan Motivasi Kerja Perawat Dengan Kinerja Perawat Di Ruang Rawat Inap Rumah Sakit Royal Prima Medan Tahun 2019." Keperawatan Dan Fisioterapi (JFK).

Perceka, Andhika Lungguh. 2018. "Pengaruh Gaya Kepemimpinan Kepala Ruangan Terhadap Kinerja Perawat Pelaksana Di Ruang Rawat Inap RSUD DR. Slamet Garut."

Purba, Jesmo Aldoran. 2018. "Hubungan Gaya Kepemimpinan Kepala Ruangan Dengan Kinerja Perawat Pelaksana Di Ruang Rawat Inap RSU Sundari."

Putra, Kadek Agus Andika Adi I, Achmad Syaifudin, and Ni Nyoman $M$ Adinatha. 2014. "Hubungan Gaya Kepemimpinan Kepala Ruangan Dengan Kinerja Perawat Pelaksana Di Rumah Sakit Umum Daerah RAA Soewondo Pati."

Samodro, Candra Alanda, and Sinta Petri Lestari. 2018. "Pengaruh Komunikasi Organisasi Atasan Bawahan Terhadap Kinerja Karyawan Koperasi BMT Fosilatama."

Sembiring, Iskandar Markus, and Novita Br Ginting Munthe. 2019. "Hubungan Komunikasi Terapeutik Perawat Dengan Kepuasan Pasien Rawat Inap." Keperawatan Dan Fisioterapi (JFK).

Triwibowo, Cecep. 2013. Manajemen Pelayanan Keperawatan Di Rumah Sakit. Jakarta Timur, DKI Jakarta: CV. Trans Info Media

Triyono. 2016. "Gaya Kepemimpinan Yang Efektif Dalam Upaya Meningkatkan Produktifitas Aanggota Polresta Bandar 


\section{KEPERAWATAN \& FISIOTERAPI (JKF)}

Jalan Sudirman No. 38 Lubuk Pakam Kab. Deli Serdang 20512 Sumatera Utara - Indonesia

Telp. 061-7952262 Fax 061-7952234, website: www.medistra.ae:id

\section{PERNYATAAN PENULIS}

Saya yang bertanda tangan dibawah ini:

$\begin{array}{ll}\text { Nama } & \text { : Nurul Wahyuni } \\ \text { Institusi } & \text { : Universitas Prima Indonesia } \\ \text { Alamat } & : \text { Jl. Sewindu No. 1A, Kel. Sei Putih Timur II, Kec. Medan Petisah } \\ \text { Email } & \text { : nurul.wahyuni1998@gmail.com } \\ \text { Judul Artikel } & : \text { Kinerja Perawat Di Ruang Rawat Inap RSU Sarah Kota Medan Ditinjau Dari } \\ & \text { Gaya Kepemimpinan Dan Komunikasi Kepala Ruangan }\end{array}$

Menyatakan bahwa saya (penulis) telah mengirimkan artikel dengan judul di atas ke Dewan Editorial Jurnal Keperawatan dan Fisioterapi (JKF) yang akan diterbitkan pada volume dan nomor berikutnya pada Jurnal Keperawatan dan Fisioterapi (JKF). Dengan ini saya mengkonfirmasi bahwa:

1. Artikel tersebut merupakan karya penulis dan belum pernah dipublikasikan oleh jurnal ilmiah lain.

2. Semua data, ide, dan pernyataan yang terkandung dalam artikel tersebut sepenuhnya menjadi tanggung jawab penulis.

3. Selama proses penulisan naskah ini, penulis tidak memiliki masalah atau konflik kepentingan dengan penulis bersama lainnya.

Saya menyatakan bahwa penyataan ini adalah benar dan sesuai dengan peraturan dan ketentuan JKF. Jika di masa depan ada kesalahan, penulis bersedia mempertanggungjawabkannya sesuai dengan undang-undang yang berlaku.

Medan, 21 Oktober 2020

Penulis,

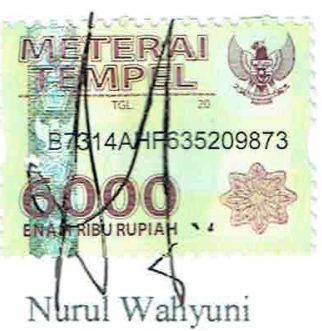

Catatan:

* Formulir Pernyataan ini diupload bersamaan dengan Manuskrip Jurnal 